\title{
Correction
}

\section{INNER WORKINGS}

Correction for "Inner Workings: Exploring ancient storms in marshes, corals, and caves," by Danielle Venton, which appeared in issue 12, March 22, 2016, of Proc Natl Acad Sci USA (113:31253126; 10.1073/pnas.1600798113).

The editors note that ref. 5 appeared incorrectly. The complete corrected reference appears below.

\footnotetext{
5. Frappier AB, et al. (2014) Two millennia of tropical cyclone-induced mud layers in a northern Yucatán stalagmite: Multiple overlapping climatic hazards during the Maya Terminal Classic "megadroughts." Geophys Res Lett 41(14):5148-5157.
}

www.pnas.org/cgi/doi/10.1073/pnas. 1605200113 